\title{
MAPPING AND VEGETATION COVER INDEX FROM CÁCERES CITY, MATO GROSSO STATE (MT), BRAZIL
}

\author{
William James VENDRAMINI ${ }^{1}$ \\ Sandra Mara Alves da Silva NEVES² \\ Jesã Pereira KREITLOW2 \\ Edineia Aparecida dos Santos GALVANIN³ \\ João Santos Vila da SILVA4
}

\begin{abstract}
Analyzing the urban space related to its own growth allows to identify the identification of the dynamics of the natural elements and the way the intensified anthropic action shapes and at the same time degrades the landscape, which in the present study is the Pantanal biome. The objective of this study is to use high resolution images and vegetation cover indexes to analyze the urban expansion of Cáceres/MT, and to generate financial support for municipal planning and management. For the execution of this research, remote sensing images and a Geographic Information System (GIS) were used, as well as demographic census data. The urban expansion contributed to the removal of $19.62 \%$ of the vegetation and to the increase of $15.28 \%$ of anthropic use. The Caceres Vegetation Cover Index is high, with vegetation percentages above $30 \%$ occurring in $74.42 \%$ of the neighborhoods. From the date of the study on the Index of Vegetation Cover for Inhabitant (ICVH) decreased by $37.20 \%$, remained at $32.55 \%$ and increased by $30.25 \%$. It was concluded that an increase in the use of urban space contributed to the reduction of vegetation, as well as the decrease of the population associated to the vegetation of the neighborhoods influenced on the decrease of the ICVH.
\end{abstract}

Key words: Geotechnologies. Planning. Green Area.

\footnotetext{
1 University of the State of Mato Grosso (UNEMAT) A student of the Graduate Program in Geography (PPGGEO) - Campus Cáceres/Geotechnology Laboratory UNEMAT (LABGEO UNEMAT). E-mail: william@unemat.br

2 University of the State of Mato Grosso (UNEMAT) - Campus Cáceres/Geotechnology Laboratory UNEMAT (LABGEO UNEMAT) . E-mails: (Teacher) ssneves@unemat.br; (Scholarship) jesapk1@hotmail.com

3 University of the State of Mato Grosso - UNEMAT/ Barra do Bugres Campus Geomatics Laboratory - UNEMAT. E-mail: (Teacher) galvaninbbg@unemat.br

${ }^{4}$ Brazilian Agricultural Research Corporation, National Center for Technological Research in Agricultural Informatics EMBRAPA, (Researcher Embrapa). E-mail: joao.vila@embrapa.br
} 


\section{Resumo}

\section{Mapeamento e Índice de Cobertura Vegetal da cidade pantaneira de Cáceres/MT, Brasil}

Analisar o espaço urbano em relação ao seu crescimento permite identificar a dinâmica dos elementos naturais e como a ação antrópica intensificada molda e, ao mesmo, tempo degrada a paisagem, que neste estudo relaciona-se ao bioma Pantanal. O objetivo deste estudo é utilizar imagens de alta resolução e índices de cobertura vegetal para análise da expansão urbana de Cáceres/MT, na perspectiva da geração de subsídios para o planejamento e a gestão municipal. Para a execução da pesquisa foram utilizados imagens de sensoriamento remoto e o Sistema de Informação Geográfica (SIG), assim como dados de população do censo demográfico. A expansão urbana contribuiu para a remoção $19,62 \%$ da vegetação e o aumento de $15,28 \%$ do uso antrópico. O Índice de Cobertura Vegetal de Cáceres é alto, ocorrendo em $74,42 \%$ dos bairros os percentuais de vegetação superiores a 30\%. Nas datas de estudo o Índice de Cobertura Vegetal por Habitante (ICVH) decresceu 37,20\%, manteve-se em 32,55\% e aumentou 30,25\%, nos bairros de Cáceres. Concluiu-se que o aumento do uso do espaço urbano contribuiu para a redução da vegetação, assim como o decréscimo da população associado ao da vegetação dos bairros influenciaram no decréscimo no ICVH.

Palavras-chave: Geotecnologias. Planejamento. Área Verdes.

\section{INTRODUCTION}

Analyzing the urban space related to its growth allows to identify the dynamics of the natural elements as well as to identify how the more intensified human action shapes and degrades the landscape at the same time. The landscape can be defined as "a portion of the space that combines biological and anthropic physical elements that react dialectically to one another and makes the landscape an unique and inseparable element" (BERTRAND, 1972 ). The landscape is a geographical category that allows the analysis of the dynamics and the impact derived from the action of society in a given area, whether urban or rural, which results can contribute to both territorial and management planning.

The urban perimeter tends to expand over time as it spontaneously attracts people from different places and regions and the population density is accelerated accelerates according to the entrepreneurial characteristics of each municipality and/ or specific needs, "especially since 1970 "(BARGOS; MATIAS, 2011), as a result of economic and population growth. In the city of Cáceres, as in most historic cities, urban expansion took place without planning, modifying landscape elements such as water, soil and vegetation, among others, according to the interests of society in different historical times. The impacts of human actions in Caceres have a direct repercussion for the floodplain of the Mato Grosso Pantanal, as well as for those which are carried out in the Upper Paraguay Basin (UPB).

Several authors such as Souza and Cunha (2007) delimit the Upper Paraguay Basin (UPB) from where it ends, at the mouth of the Paraná River, on the border between Brazil and Paraguay. That all covers a region named "Pantanal" which is temporarily and partially flooded by the Paraguay river and its main tributaries each year, passing through the municipality of Cáceres/MT, among other municipalities, being of fundamental importance for modeling the landscape as well as for the maintenance of the life of this invironment that is fragile to human actions. 
The improvement of the Geographic Information System (GIS) and the automation of the administrative procedures allow to establish the urbanization process with increasingly sophisticated instrumentsthat facilitate the decision making on urban operations with a high degree of complexity. "Allied to this process of modernization, we must also transcend the sectorial planning of cities, which has prevented the achievement of a global vision of its problems and the formulation of an integrated model for its future development" (FARINA, 2006).

Bargos and Matias (2011) and Romanos (2011) stated that the characterization of urban areas covered with vegetation are relevant for development planning because understanding the evolution of alterations suffered by spaces and landscapes are an indispensable reorientation in land use and occupation is necessary. It is expected that the results from this work will result in financial support for both planning and municipal management. For Rabelo and Rodrigues (2013), urban planning and municipal management must be in agreement with the guidelines of the Master Plan.

Regarding the analysis of landscape dynamics related to city growth from the process of space appropriation, it is observed that the waterproofing of lots and the consequent decrease of vegetation cover is one of the most noticeable factors that causes the "decrease of environmental functionalities, from which vegetation is significantly responsible " (MASCARÓ, 2005). This author stated that "vegetation acts on climatic elements in urban microclimates, contributing to the control of solar radiation, temperature and air humidity, action of winds and rain and reducing air pollution" (MASCARÓ ,1996).

The vegetation is present and necessary within the urban context, however, it must be planned to ensure the perpetuation of the various levels of niches. In the Pantanal, the vegetation has characteristics which makes it fragile to human activities. Within the urban environment this ecosystem is more degraded.

As for the importance of vegetation "[...] the need that man has of vegetation extrapolates a merely sentimental or aesthetic value" (MONTEIRO, 1976). "[...] not even a shrub could be sacrificed in the name of inevitable constructions in the city - on the contrary, all existing vegetation should be enlarged by new afforestation" (SITTE, 1992). Thus, the vegetative cover, both qualitatively and quantitatively, and also its spatial distribution, "must be carefully considered in the evaluation of environmental quality (NUCCI, 1999).

In this sense, there are some tools that contribute to urban planning, among them are the indexes that evaluate the vegetal cover. NUCCI (2001) defines vegetation cover as "patches of vegetation" seen with the naked eye in a city and considers all afforestation of streets, squares, flowerbeds, public areas and private areas. Authors such as Henke-Oliveira (1996) and Bargos and Matias (2011) consider that these are a basic tool for urban planning, since they enable the public authority to evaluate the public areas to meet the demands for green areas and diverse urban equipments.

Mitigating measures to balance the damages of urbanization to the environment can be simple through the following measures:

Opening of more parks and squares, planting of trees adapted to the environment, afforestation of road and sidewalks (permeable), forest gardens, construction of public gardens, etc. These artificial attitudes allow the recuperation and preservation of fauna and flora, making urban life less harmful (SCHEUER; NEVES, 2016).

In view of the above, the objective of this study is to use high resolution satellite images and vegetation cover indexes to analyze the urban expansion of Cáceres/MT, expecting to generate financial support for both municipal planning and management. 


\section{MATERIALS AND METHODS}

\section{Area under study}

The city of Cáceres is located on the left bank of Rio Paraguay, the main watercourse within the Pantanal biome, with a territorial area of $68.95 \mathrm{~km}^{2}$ (Figure 1), comprising officially forty-three districts and distant $215 \mathrm{~km}$ from the capital Cuiabá (COCHEV et al., 2010). The city was built on the geomorphological unit Depression of Rio Paraguay, located between the Pantanal of Cáceres, subunit of the Mato Grosso Pantanal, and the so-called Serrana Province.

According to Neves et al. (2011) the climate occurring in the city is tropical hot and humid, third mega-thermic, which average temperature of the coldest month is over $18^{\circ} \mathrm{C}$, with dry winter (May to October) and rainfall in the summer (November to April).

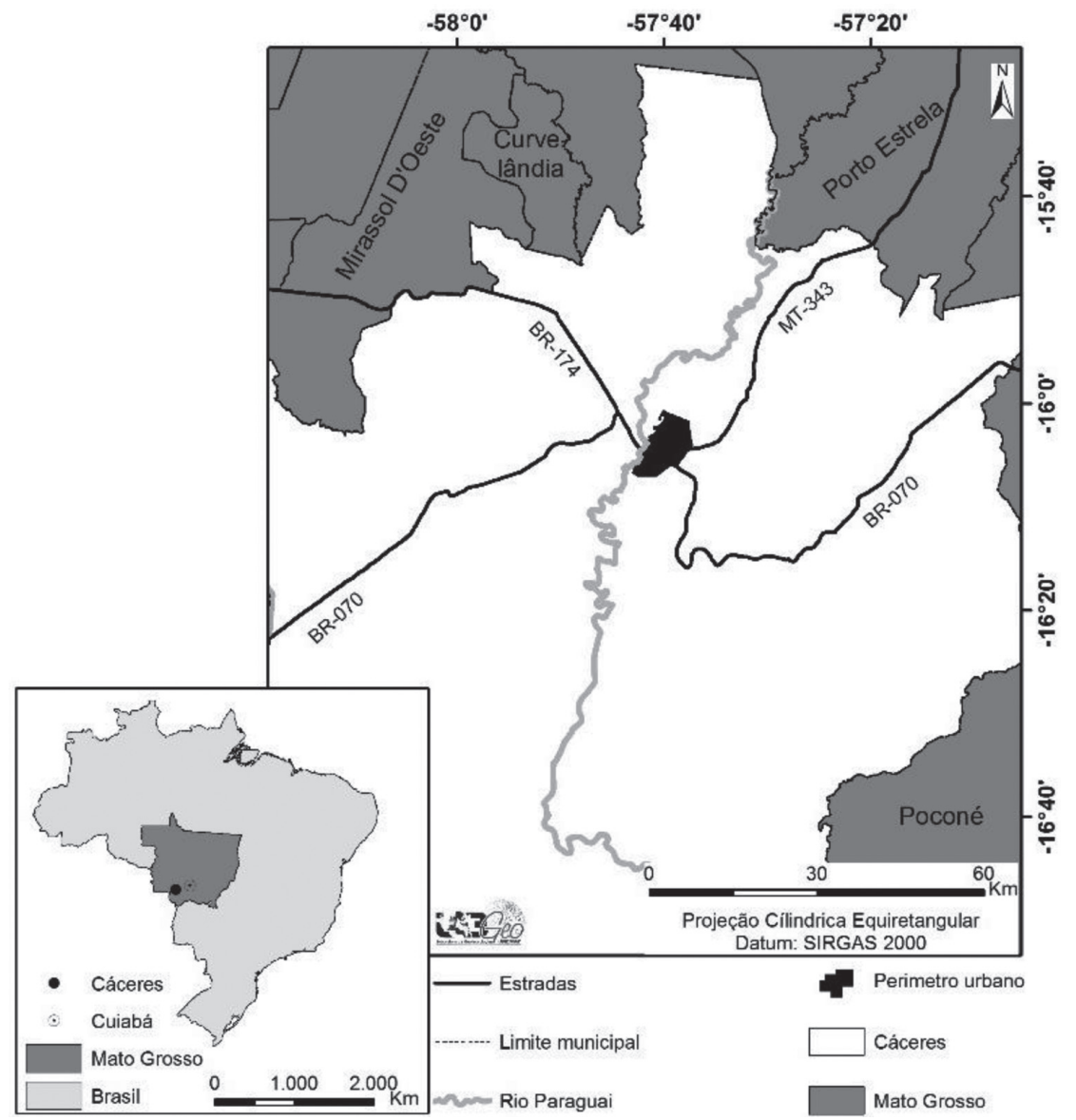

Figure 1 - Area under study in the local, regional, and national contextof UPB in Mato Grosso State, Pantanal and Cáceres municipality

Source: LabGeo Unemat (2016). 


\section{Methodologic procedures}

The vegetation cover and land use map of Cáceres city was generated using 2005 QuickBird satellite images with a spatial resolution of $60 \mathrm{~cm}$ and 2016 WordViewscenes with a spatial resolution of $30 \mathrm{~cm}$. Initially, both images were orthorectified and the classification procedure was done with the software ArcGis, version 10.5 (ESRI, 2017).

Three thematic classes were defined, namely: Water, Vegetation and Anthropic areas. The classification matrix files were converted to vectors and exported. The layouts and quantifications were generated using ArcGis.

The population data, the income of inhabitants, and the cartographic base from neighborhoods of the area under study were obtained from the Brazilian Institute for Geography and Statistics (IBGE, 2016), referring to the years 2000 and 2010. They were tabulated and systematized with the Microsoft Excel softwareafterwards.

The Minitab 16 software and the Kolmogorov-Smirnov test were used to verify the normality of the data, considering a $95 \%$ confidence level. After verifying the nonnormality of the data, the Spearman correlation method was used for vegetation cover data and land use, population and income level to verify the relationship between them. Considering the $p$ - Value at ${ }^{\sim}=0.05$, the significance of the correlation coefficient was verified.

The values of Green Areas from the Neighborhoods $\left(\mathrm{m}^{2}\right)$ of the Plant Cover Index were obtained by quantifying the vegetation class of the vegetation cover map and land use. The area of the neighborhoods $\left(\mathrm{m}^{2}\right)$ was calculated from the cartographic base. The number of inhabitants per neighborhood was obtained from the IBGE site, using the IBGE Automatic Recovery System (SIDRA).

The Vegetation Cover Indexes (ICV) and the Vegetation Cover Index per Inhabitant (ICVH) are given by:

where:

$$
\mathrm{ICV}=\sum \frac{\mathrm{AVBr}}{\mathrm{SABr}} * 100
$$

AVBr: Green Area of Neighborhood $\left(\mathrm{m}^{2}\right)$

$\mathrm{SABr}$ : Area of neighborhoods $\left(\mathrm{m}^{2}\right)$

where:

$$
\mathrm{ICVH}=\sum \frac{\mathrm{AVBr}}{\mathrm{NHBr}} * 100
$$

AVBr: Green Area of Neighborhoods $\left(\mathrm{m}^{2}\right)$

$\mathrm{NHBr}$ : Number of Inhabitants per Neighborhood

The parameters from the analysis of the Vegetation Cover Index of urban areas were modified from BORGES et al. (2012), according to Table 1. 
Table 1 - Classes of Vegetation Cover

\begin{tabular}{ccc}
\hline Until $10 \%$ & 11 to $29 \%$ & Above $30 \%$ \\
\hline Low & Medium & High \\
\hline
\end{tabular}

\section{RESULTS AND DISCUSSION}

The expansion of a city involves different activities which alter the urban landscape. It can be progressive with or without planning. The municipal management must ensure that the process of growth occurs in an organized way, considering that anthropic actions reflect on the biotic and abiotic elements of the landscape.

Land use in Cáceres increased by $15.28 \%$ in the period investigated (Table 1 and Figure 2), mainly due to the implantation of housing complexes in the Northeast, South, Southwest and Central South regions, in the outlying districts of Olhos D'água (29), Vila Real (42), Santos Dumont (35) and Jardim Guanabara (15) respectively, due to the Program My Home My Life from the federal government - Law 11,977/2009 (BRASIL, 2009), 12,424/2011 (BRASIL, 2011) and Decree no 6.820/2009 (BRASIL, 2009) - favoring the horizontal occupation of areas that by that time had no infrastructure and were covered byvegetation.

These popular housing programs caused a chain reaction, creating other allotments in the surroundings, as well as especially commercial ventures, which were attracted by the new population concentration. This new population concentration has changed the form of land use/occupation, also contributing to the removal of the vegetation cover, thus influencing the quality and quantity of water from the modified place.

In this case, considering the population distribution in space, is as important as its growth, since the human agglomerations are responsible factors for part of the problems related to the environment. SIQUEIRA \& MORAES (2009) corroborate these issues, stating that the larger the population, the greater the production of waste, therefore, the stronger the level of environment degradation, due to the reduction of the environmental capacity to assimilate the huge waste load accumulated in it.

The urban network in the period evaluated did not expand in the West, Southwest, Northwest and North directions due to the Rio Paraguay river channel - the main water course of the Pantanal biome (Figure 2).

During the period under study (2005 - 2016), the vegetation cover was reduced by $14.18 \%$, varying according to the neighborhood, such as at Cidade Alta (7) and Nova Era (28). This situation can be considered detrimental to the Caceres populationdue to the functions performed by vegetation for the Improvement of environmental quality, such as: thermal comfort; noise mitigation, visual and air pollution; breaking the artificial urban environment, among other functions (GOMES \& QUEIROZ, 2011).

The expansion of the built up area in the time lapse mentioned was $37.87 \%$, especially in the neighborhoods: Jardim Guanabara (15), Joaquim Murtinho (21), Junco (22), Lobo (24), Olhos D'água (29), Santos Dumont (35) and Vila Real (42).

The piped water component is not present in all districts, however, those ones that have it present progressive increases of its use, especially the districts of Bettel (01), DNER (11) and Vila Real (42). The last one showed a decrease of $250.83 \%$, especially in the Garcês neighborhood (Table 1). 
Table 2 - Dynamics of urban landscape components of neighborhoods from Cáceres /MT

\begin{tabular}{|c|c|c|c|c|c|c|c|c|c|}
\hline \multirow[t]{2}{*}{ Bairro (Código no mapa) } & \multicolumn{2}{|c|}{ Água $\left(\mathrm{m}^{2}\right)$} & \multirow{2}{*}{$\begin{array}{c}\text { Dinâmica } \\
(\%)\end{array}$} & \multicolumn{2}{|c|}{ Uso $\left(m^{2}\right)$} & \multirow{2}{*}{$\begin{array}{c}\text { Dinâmica } \\
(\%)\end{array}$} & \multicolumn{2}{|c|}{ Vegetação $\left(\mathrm{m}^{2}\right)$} & \multirow{2}{*}{$\begin{array}{c}\text { Dinâmica } \\
(\%)\end{array}$} \\
\hline & 2005 & 2016 & & 2005 & 2016 & & 2005 & 2016 & \\
\hline Betel (1) & $1.724,54$ & 181,46 & $-850,38$ & $104.206,81$ & $135.649,08$ & 23,18 & $690.134,52$ & $660.235,34$ & $-4,53$ \\
\hline Carrapatinho (2) & $19.515,14$ & $17,616,73$ & $-10,78$ & $1.293 .054,23$ & $2.247 .244,36$ & 42,46 & $11.862 .923,47$ & $10.910 .631,75$ & $-8,73$ \\
\hline Cavalhada I (3) & $23.939,05$ & 13,18 & $-181.489,93$ & $464.199,82$ & $799.759,50$ & 41,96 & $1.033 .848,42$ & $722.214,19$ & $-43,15$ \\
\hline Cavalhada II (4) & 0 & 0 & - & $385.231,30$ & $134.601,08$ & $-186,20$ & $290.990,48$ & $541.620,70$ & 46,27 \\
\hline Cavalhada III (5) & 0 & 0 & - & $275.015,92$ & $415.342,00$ & 33,79 & $485.304,47$ & $344.978,39$ & $-40,68$ \\
\hline Centro (6) & $20.028,02$ & 0 & - & $1.240 .781,46$ & $1.583 .191,27$ & 21,63 & $693.264,81$ & $370.883,02$ & $-86,92$ \\
\hline Cidade Alta (7) & 0 & 0 & - & $88.712,98$ & $137.491,36$ & 35,48 & $71.750,27$ & $22.971,89$ & $-212,34$ \\
\hline Cidade Nova (8) & 0 & 0 & - & $332.776,32$ & $495.618,29$ & 32,86 & $312.631,05$ & $149.789,08$ & $-108,71$ \\
\hline Cohab Nova (9) & $3.560,34$ & 0 & - & $233.181,56$ & $353.816,01$ & 34,10 & $696.251,08$ & $579.176,96$ & $-20,21$ \\
\hline Cohab Velha $(10)$ & 0 & 0 & - & $238.795,85$ & $278.640,14$ & 14,30 & $61.120,60$ & $21.276,32$ & $-187,27$ \\
\hline DNER (11) & $8.461,89$ & 784,05 & $-979,25$ & $246.282,42$ & $391.035,85$ & 37,02 & $1.173 .049,36$ & $1.035 .973,77$ & $-13,23$ \\
\hline Garcês (12) & $18.674,05$ & 77,56 & $-23.976,93$ & $308.178,11$ & $382.598,72$ & 19,45 & $3.253 .384,62$ & $3.197 .560,50$ & $-1,75$ \\
\hline Jardim Celeste (13) & 0 & 0 & - & $311.958,35$ & $490.912,25$ & 36,45 & $746.035,69$ & $567.081,79$ & $-31,56$ \\
\hline Jardim do Trevo (14) & 0 & 0 & - & $268.142,43$ & $378.906,02$ & 29,23 & $451.811,50$ & $341.047,91$ & $-32,48$ \\
\hline Jardim Guanabara (15) & 0 & $1.044,25$ & 100 & $195.298,36$ & $459.531,39$ & 57,50 & $1.469 .204,60$ & $1.203 .927,32$ & $-22,03$ \\
\hline Jardim Imperial (16) & $71.812,11$ & $21.235,03$ & $-238,18$ & $441.330,33$ & $669.522,27$ & 34,08 & $740.120,39$ & $562.505,53$ & $-31,58$ \\
\hline Jardim Marajoara (17) & 0 & 0 & - & $245.468,04$ & $483.217,83$ & 49,20 & $344.674,65$ & $106.924,86$ & $-222,35$ \\
\hline Jardim Padre Paulo (18) & $1.010,16$ & $1.024,26$ & 1,38 & $306.210,33$ & $513.205,82$ & 40,33 & $1.214 .679,77$ & $1.007 .670,18$ & $-20,54$ \\
\hline Jardim Paraíso (19) & $45.210,76$ & $38.129,97$ & $-18,57$ & $288.212,31$ & $473.656,65$ & 39,15 & $611.215,10$ & $432.851,55$ & $-41,21$ \\
\hline Jardim São Luiz (20) & $6.210,31$ & 0 & - & $423.669,25$ & $598.895,31$ & 29,26 & $385.384,04$ & $216.368,29$ & $-78,11$ \\
\hline Joaquim Murtinho (21) & $5.258,59$ & $10.666,19$ & 50,70 & $327.176,02$ & $822.700,06$ & 60,23 & $2.024 .226,64$ & $1.523 .295,00$ & $-32,88$ \\
\hline Junco (22) & 0 & 0 & - & $331.466,93$ & $759.843,83$ & 56,38 & $1.382 .489,91$ & $954.113,01$ & $-44,90$ \\
\hline Lavapés (23) & $1.557,14$ & $1.739,73$ & 10,50 & $230.908,49$ & $363.096,08$ & 36,41 & $354.709,11$ & $222.338,93$ & $-59,54$ \\
\hline Lobo (24) & $1.917,67$ & 0 & - & $197.441,97$ & $630.630,21$ & 68,69 & $4.430 .890,03$ & $3.999 .619,46$ & $-10,78$ \\
\hline Maracanãzinho (25) & 651,91 & 0 & - & $182.914,88$ & $282.508,45$ & 35,25 & $190.663,99$ & $91.722,33$ & $-107,87$ \\
\hline Massa Barro (26) & 0 & 0 & - & $131.833,37$ & $214.789,49$ & 38,62 & $212.777,95$ & $129.821,83$ & $-63,90$ \\
\hline Monte Verde (27) & 0 & 0 & - & $135.131,91$ & $186.351,19$ & 27,49 & $79.317,37$ & $28.098,09$ & $-182,29$ \\
\hline Nova Era (28) & 0 & 0 & - & $315.937,91$ & $447.476,11$ & 29,40 & $1.521 .353,15$ & $1.389 .814,95$ & $-9,46$ \\
\hline Olho D' Água (29) & $149.151,20$ & 0 & - & $233.316,90$ & $507.333,78$ & 54,01 & $10.205 .561,34$ & $10.080 .695,65$ & $-1,24$ \\
\hline Rodeio (30) & $1.841,17$ & 0 & - & $266.987,41$ & $450.767,87$ & 40,77 & $761.218,27$ & $579.278,98$ & $-31,41$ \\
\hline Santa Cruz (31) & $2.623,64$ & 0 & - & $356.975,18$ & $490.590,20$ & 27,24 & $331.761,27$ & $200.769,89$ & $-65,24$ \\
\hline Santa Isabel (32) & 0 & 0 & - & $184.010,03$ & $276.333,61$ & 33,41 & $126.017,15$ & $33.693,57$ & $-274,01$ \\
\hline Santa Rosa (33) & $101.145,32$ & $35.016,49$ & $-188,85$ & $212.766,83$ & $512.487,59$ & 58,48 & $1.869 .627,81$ & $1.636 .035,88$ & $-14,28$ \\
\hline Santo Antônio (34) & $4.153,79$ & $9.156,26$ & 54,63 & $161.318,25$ & $181.974,68$ & 11,35 & $913.283,17$ & $887.624,27$ & $-2,89$ \\
\hline Santos Dumont (35) & 0 & 0 & - & $99.542,25$ & $203.391,07$ & 51,06 & $1.523 .241,14$ & $1.419 .409,74$ & $-7,32$ \\
\hline São Jorge (36) & 0 & 0 & - & $67.030,54$ & $92.795,39$ & 27,77 & $153.101,08$ & $127.336,22$ & $-20,23$ \\
\hline São Lourenço (37) & 0 & 0 & - & $99.465,27$ & $129.016,56$ & 22,91 & $161.107,30$ & $131.556,01$ & $-22,46$ \\
\hline São Miguel (38) & $4.148,29$ & 0 & - & $87.120,56$ & $117.286,27$ & 25,72 & $78.072,40$ & $52.054,98$ & $-49,98$ \\
\hline Vila Irene (39) & 0 & 0 & - & $130.027,16$ & $231.950,80$ & 43,94 & $322.569,83$ & $220.646,19$ & $-46,19$ \\
\hline Vila Mariana (40) & 0 & 0 & - & $441.431,95$ & $551.154,53$ & 19,91 & $198.172,17$ & $88.449,58$ & $-124,05$ \\
\hline Vila Nova (41) & 0 & 0 & - & $127.820,29$ & $190.491,19$ & 32,90 & $479.718,22$ & $417.047,33$ & $-15,03$ \\
\hline Vila Real (42) & $30.402,33$ & $7.053,67$ & $-331,01$ & $291.852,56$ & $802.946,53$ & 63,65 & $2.250 .522,47$ & $1.762 .777,16$ & $-27,67$ \\
\hline Vitória Régia (43) & $5.999,56$ & $7.044,99$ & 14,84 & $305.700,20$ & $424.480,40$ & 27,98 & $516.758,22$ & $396.932,59$ & $-30,19$ \\
\hline
\end{tabular}

Data source: IBGE (2005) and IBGE (2012). Org.: The Authors (2016). 

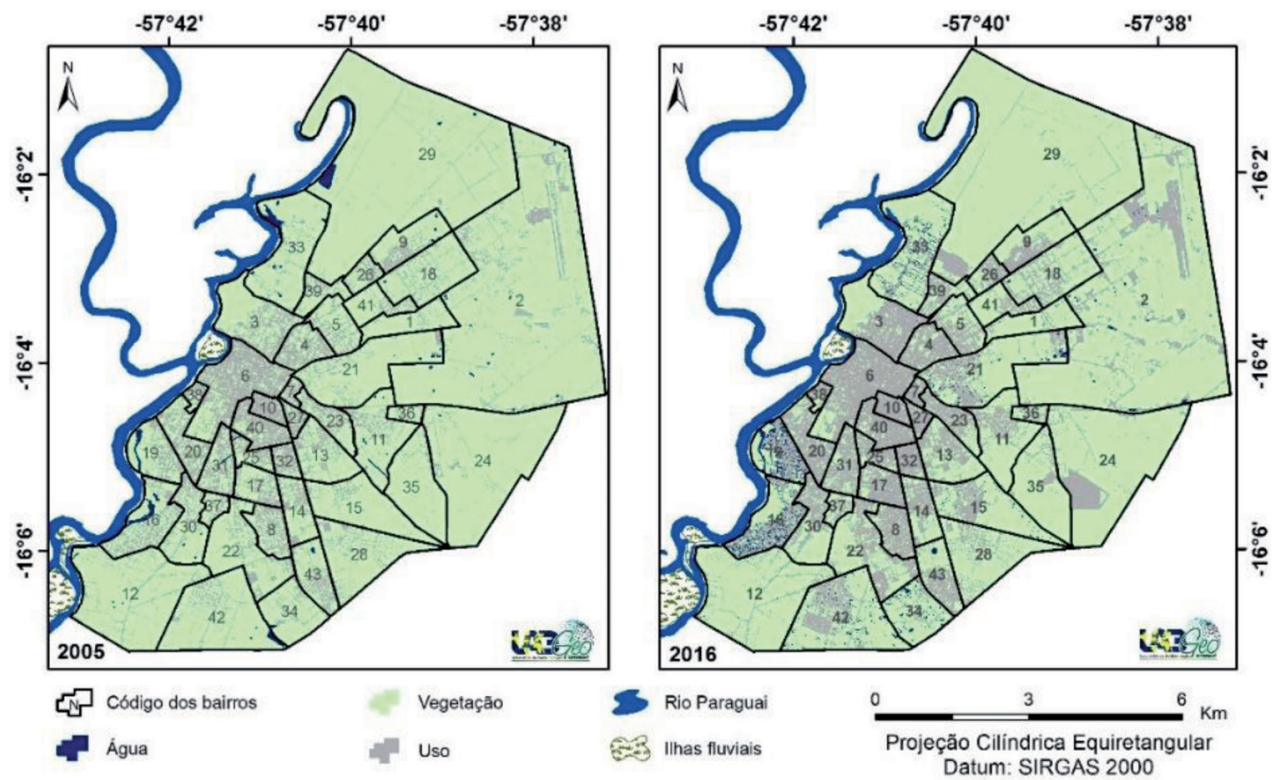

Figure 2 - Vegetation cover and urban land use in 2005 and 2016

Source: the authors. $\mathrm{N}=$ Code of neighborhoods presented on the tables.

The population decreased by $8 \%$ between 2000 and 2010 in several neighborhoods, except for the districts of: Betel (01), Carrapatinho (02), Jardim Paraíso (19), Massa Barro (26), Olhos D'água (42), which are peripheral neighborhoods to the Centro district (06). In Olhos D'água (29) and Vila Real (42) neighborhoods, housing projects were implemented, which population has a lower income than the average of other inhabitants from the city. However, this did not prevent the general increase of urban income by 53\%, even in peripheral neighborhoods such as Betel (01) and Nova Era (28), where the income increase was over $100 \%$.

A pattern of decreasing vegetation cover was found, related to the population growth at more peripheral districts such as Olhos D'água (29), Nova Era (28), Vila Irene (39) and Vila Real (42), associated to the income increase, because in all of these neighborhoods there was an increase both in per capita income and land use/ cover, in parallel with a decrease of vegetation.

Another aspect refers to the occupation of empty spaces within the urban perimeter, which is a natural trend of the city's evolution. In the area under study, there are still many spaces to be occupied which can be done in an organized way to minimize the environmental impacts in the city.

The analysis of population and income totals by districts (Table 3 ) were very noticeable in the opposite direction of what was expected, which would be the gradual natural or forced increase, due to the attraction for employment or quality of life, unlikely the trend in Brazilian Central West region, where from the 1970's onwards the urbanization occurred more intensely (OLIVEIRA; SIMÕES, 2005, p. 2).

The results of Spearman's correlation coefficient among the variables land use, population, and income, followed by the $\mathrm{p}$-value respectively, are presented on Table 4. 
Table 3 - Demographic and economic data from Cáceres/MT urban population

\begin{tabular}{|c|c|c|c|c|c|c|}
\hline \multirow{2}{*}{$\begin{array}{l}\text { Neighborhood } \\
\text { (Code on Map) }\end{array}$} & \multicolumn{2}{|c|}{ Population } & \multirow{2}{*}{$\begin{array}{c}\text { Dynamic } \\
\%\end{array}$} & \multicolumn{2}{|c|}{ Income } & \multirow{2}{*}{$\begin{array}{c}\text { Dynamic } \\
\% \\
\end{array}$} \\
\hline & 2000 & 2010 & & 2000 & 2010 & \\
\hline Betel (1) & 427 & 635 & 49 & 12.600 & 109.451 & 769 \\
\hline Carrapatinho (2) & 230 & 260 & 13 & 16.823 & 57.694 & 243 \\
\hline Cavalhada I (3) & 2.048 & 2.289 & 12 & 697.529 & 1.725 .098 & 147 \\
\hline Cavalhada II (4) & 2.200 & 1.730 & -21 & 410.866 & 838.766 & 104 \\
\hline Cavalhada III (5) & 2.226 & 1.116 & -50 & 183.689 & 243.310 & 32 \\
\hline Centro $(6)$ & 5.197 & 5.017 & -3 & 2.007 .757 & 3.779 .060 & 88 \\
\hline Cidade Alta (7) & 965 & 753 & -22 & 102.159 & 253.767 & 148 \\
\hline Cidade Nova (8) & 1.840 & 1.058 & -43 & 212.035 & 286.307 & 35 \\
\hline Cohab Nova (9) & 2.515 & 1.625 & -35 & 477.442 & 688.451 & 44 \\
\hline Cohab Velha (10) & 2.050 & 1.767 & -14 & 534.349 & 1.070 .166 & 100 \\
\hline DNER (11) & 1.997 & 1.834 & -8 & 167.057 & 344.807 & 106 \\
\hline Garcês (12) & 1.296 & 781 & -40 & 68.119 & 139.893 & 105 \\
\hline Jardim Celeste (13) & 1.217 & 627 & -48 & 121.106 & 176.400 & 46 \\
\hline Jardim do Trevo (14) & 643 & 547 & -15 & 185.389 & 400.794 & 116 \\
\hline Jardim Guanabara (15) & 1.186 & 692 & -42 & 205.450 & 260.178 & 27 \\
\hline Jardim Imperial (16) & 1.549 & 1.280 & -17 & 96.650 & 250.500 & 159 \\
\hline Jardim Marajoara (17) & 2.417 & 2.249 & -7 & 219.441 & 455.111 & 107 \\
\hline Jardim Padre Paulo (18) & 1.336 & 569 & -57 & 208.572 & 172.633 & -17 \\
\hline Jardim Paraíso (19) & 1.526 & 1.608 & 5 & 103.088 & 287.939 & 179 \\
\hline Jardim São Luiz (20) & 2.046 & 1.046 & -49 & 199.262 & 278.836 & 40 \\
\hline Joaquim Murtinho (21) & 542 & 694 & 28 & 69.199 & 161.622 & 134 \\
\hline Junco $(22)$ & 345 & 259 & -25 & 19.800 & 40.201 & 103 \\
\hline Lavapés (23) & 1.555 & 1.364 & -12 & 239.221 & 474.735 & 98 \\
\hline Lobo (24) & 1.721 & 1.761 & 2 & 167.658 & 361.330 & 116 \\
\hline Maracanãzinho (25) & 1.099 & 1.385 & 26 & 72.364 & 263.292 & 264 \\
\hline Massa Barro (26) & 1.160 & 452 & -61 & 424.517 & 167.368 & -61 \\
\hline Monte Verde (27) & 1.351 & 1.959 & 45 & 68.577 & 245.316 & 258 \\
\hline Nova Era (28) & 472 & 959 & 103 & 30.476 & 175.152 & 475 \\
\hline Olho D' Água (29) & 2.203 & 1.387 & -37 & 182.773 & 261.635 & 43 \\
\hline Rodeio (30) & 1.965 & 1.484 & -24 & 334.403 & 608.270 & 82 \\
\hline Santa Cruz (31) & 1.174 & 488 & -58 & 213.197 & 238.520 & 12 \\
\hline Santa Isabel (32) & 489 & 612 & 25 & 132.528 & 249.981 & 89 \\
\hline Santa Rosa (33) & 1.001 & 1.215 & 21 & 80.475 & 262.881 & 227 \\
\hline Santo Antônio (34) & 1.089 & 976 & -10 & 61.893 & 111.706 & 80 \\
\hline Santos Dumont (35) & 432 & 401 & -7 & 48.720 & 144.778 & 197 \\
\hline
\end{tabular}




\begin{tabular}{lrrrrrr} 
São Jorge (36) & 832 & 816 & -2 & 42.988 & 119.389 & 178 \\
São Lourenço (37) & 1.734 & 1.749 & 1 & 214.190 & 560.828 & 162 \\
São Miguel (38) & 771 & 678 & -12 & 202.076 & 181.381 & -10 \\
Vila Irene (39) & 1.348 & 721 & -47 & 82.764 & 171.306 & 107 \\
Vila Mariana (40) & 2.736 & 2.164 & -21 & 498.268 & 1.134 .783 & 128 \\
Vila Nova (41) & 1.370 & 741 & -46 & 90.344 & 140.095 & 55 \\
Vila Real (42) & 1.401 & 1.255 & -10 & 129.100 & 328.291 & 154 \\
Vitória Régia (43) & 2.005 & 1.480 & -26 & 241.786 & 377.481 & 56 \\
\hline Total & $\mathbf{6 3 . 7 0 6}$ & $\mathbf{5 2 . 4 8 3}$ & & $\mathbf{9 . 8 7 6 . 7 0 0}$ & $\mathbf{1 8 . 5 9 9 . 5 0 2}$ & \\
\hline
\end{tabular}

Data source: IBGE (2000) and IBGE (2012). Org.: The authors (2016).

\section{Table 4 - Spearman's correlation matrix for proximal variables}

\begin{tabular}{lccccc}
\hline & Water & Use & Vegetation & Population & Income \\
\hline Water & 1 & & & & \\
Use & $0,334^{*}$ & 1 & & & \\
Vegetation & $\mathbf{0 , 5 1 3 *}$ & $\mathbf{0 , 4 7 8 *}$ & 1 & & \\
Population & $-0,030 * *$ & $0,097 * *$ & $-0,155 * *$ & 1 & \\
Income & $-0,134 * *$ & $0,169 * *$ & $-0,243 * *$ & $\mathbf{0 , 7 8 2} *$ & 1 \\
\hline
\end{tabular}

* Significant to $5 \%$ Probability $* *$ Not significant. Org. The authors (2016).

It was verified that there is a correlation between land use and vegetation (Table 4), since the elimination of vegetation cover increased with the use of it. There is a correlation between population and income, which in theory is due to the fact that the larger the population of a neighborhood, the greater the urbanization and the higher the urban environmental impacts. This can be identified from the analysis of census neighborhoods data (Table 2) complemented with the land use and vegetation cover map (Figure 2).

In this case, it is important to emphasize that although "structural measures" are taken, the application of "non-structural measures" is also necessary, which are correlated to the situation (SANTOS, 1988).

In Cáceres, the disordered growth is a reality verified by Cochev et al. (2010), by a visual interpretation of merged CBERS-IIB satellite image, which shows the absence of implementation of urban planning measures foreseen in the Master Plan, as well as the non-execution of public policies directed to spatial planning.

Thus, it is necessary to think of analysis methods that can evaluate the issue of urban environmental impacts, considering that these are directly associated with the urban expansion of Cáceres. Thereby, it is important to rely on geotechnologies to have a macro view of the city and therefore meet the needs of planning and management directly and indirectly in the short, medium, and long term, in agreement with Florenzano (2011, p. 3): "satellite images provide a synoptic (overall) and multitemporal (at different dates) view of large areas of the Earth surface". 


\section{Analysis of the Vegetation Cover Index (ICV) and Vegetation Cover Index per} Inhabitant (ICVH)

Most neighborhoods (74.42\%) of Cáceres have a high ICV (Table 5) because their spaces are covered by more than $30 \%$ of vegetation. Although there is a predominance of a high ICV, a vegetation decrease in $97.67 \%$ of the districts was identified, as it can be seen in Table 5, except for the neighborhood of Cavalhada II (04).

Thus, the percentage of green areas of a neighborhood or a city are essential for "well-being and thermal equilibrium", emphasizing the importance of "planning and management of natural areas" in the urban perimeter (MELO; ROMANINI, 2007). This aspect should be observed by the municipal government when planning the expansion of the urban network, caring to preserve the environment as much as possible.

\section{Table 5 - Indexes on the vegetation cover from Cáceres/MT city}

\begin{tabular}{|c|c|c|c|c|c|c|}
\hline \multirow{2}{*}{$\begin{array}{l}\text { Neighborhood } \\
\text { (Code on Map) }\end{array}$} & \multicolumn{2}{|c|}{ ICV (\%) } & \multirow{2}{*}{$\begin{array}{c}\text { Dynamic } \\
\%\end{array}$} & \multicolumn{2}{|c|}{ ICVH $\left(\mathrm{m}^{2}\right)$} & \multirow{2}{*}{$\begin{array}{c}\text { Dynamic } \\
\%\end{array}$} \\
\hline & 2005 & 2016 & & 2005 & 2016 & \\
\hline Betel (1) & 86,69 & 82,94 & $-4,53$ & $1.616,24$ & $1.039,74$ & $-55,45$ \\
\hline Carrapatinho (2) & 89,96 & 82,74 & $-8,73$ & $51.577,93$ & $41.963,97$ & $-22,91$ \\
\hline Cavalhada I (3) & 67,93 & 47,45 & $-43,15$ & 504,81 & 315,52 & $-60,00$ \\
\hline Cavalhada II (4) & 43,03 & 80,10 & 46,27 & 132,27 & 313,08 & 57,75 \\
\hline Cavalhada III (5) & 63,83 & 45,37 & $-40,68$ & 218,02 & 309,12 & 29,47 \\
\hline Centro (6) & 35,48 & 18,98 & $-86,92$ & 133,40 & 73,93 & $-80,45$ \\
\hline Cidade Alta (7) & 44,71 & 14,32 & $-212,34$ & 74,35 & 30,51 & $-143,72$ \\
\hline Cidade Nova (8) & 48,44 & 23,21 & $-108,71$ & 169,91 & 141,58 & $-20,01$ \\
\hline Cohab Nova (9) & 74,63 & 62,08 & $-20,21$ & 276,84 & 356,42 & 22,33 \\
\hline Cohab Velha (10) & 20,38 & 7,09 & $-187,27$ & 29,81 & 12,04 & $-147,61$ \\
\hline DNER (11) & 82,16 & 72,56 & $-13,23$ & 587,41 & 564,87 & $-3,99$ \\
\hline Garcês (12) & 90,87 & 89,31 & $-1,75$ & $2.510,33$ & $4.094,19$ & 38,69 \\
\hline Jardim Celeste (13) & 70,51 & 53,60 & $-31,56$ & 613,01 & 904,44 & 32,22 \\
\hline Jardim do Trevo (14) & 62,76 & 47,37 & $-32,48$ & 702,66 & 623,49 & $-12,70$ \\
\hline Jardim Guanabara (15) & 88,27 & 72,33 & $-22,03$ & $1.238,79$ & $1.739,78$ & 28,80 \\
\hline Jardim Imperial (16) & 59,06 & 44,88 & $-31,58$ & 477,81 & 439,46 & $-8,73$ \\
\hline Jardim Marajoara (17) & 58,41 & 18,12 & $-222,35$ & 142,60 & 47,54 & $-199,95$ \\
\hline Jardim Padre Paulo (18) & 79,81 & 66,21 & $-20,54$ & 909,19 & $1.770,95$ & 48,66 \\
\hline Jardim Paraíso (19) & 64,70 & 45,82 & $-41,21$ & 400,53 & 269,19 & $-48,79$ \\
\hline Jardim São Luiz (20) & 47,27 & 26,54 & $-78,11$ & 188,36 & 206,85 & 8,94 \\
\hline Joaquim Murtinho (21) & 85,89 & 64,64 & $-32,88$ & $3.734,74$ & $2.194,95$ & $-70,15$ \\
\hline Junco (22) & 80,66 & 55,67 & $-44,90$ & $4.007,22$ & $3.683,83$ & $-8,78$ \\
\hline Lavapés (23) & 60,41 & 37,87 & $-59,54$ & 228,11 & 163,01 & $-39,94$ \\
\hline Lobo (24) & 95,69 & 86,38 & $-10,78$ & $2.574,60$ & $2.271,22$ & $-13,36$ \\
\hline Maracanãzinho (25) & 50,95 & 24,51 & $-107,87$ & 173,49 & 66,23 & $-161,97$ \\
\hline Massa Barro (26) & 61,74 & 37,67 & $-63,90$ & 183,43 & 287,22 & 36,14 \\
\hline Monte Verde (27) & 36,99 & 13,10 & $-182,29$ & 58,71 & 14,34 & $-309,33$ \\
\hline Nova Era (28) & 82,80 & 75,64 & $-9,46$ & $3.223,21$ & $1.449,23$ & $-122,41$ \\
\hline Olho D' Água (29) & 96,39 & 95,21 & $-1,24$ & $4.632,57$ & $7.267,99$ & 36,26 \\
\hline Rodeio (30) & 73,90 & 56,24 & $-31,41$ & 387,39 & 390,35 & 0,76 \\
\hline
\end{tabular}




\begin{tabular}{lrrrrrr} 
Santa Cruz (31) & 47,99 & 29,04 & $-65,24$ & 282,59 & 411,41 & 31,31 \\
Santa Isabel (32) & 40,65 & 10,87 & $-274,01$ & 257,70 & 55,05 & $-368,09$ \\
Santa Rosa (33) & 85,62 & 74,93 & $-14,28$ & $1.867,76$ & $1.346,53$ & $-38,71$ \\
Santo Antônio (34) & 84,66 & 82,28 & $-2,89$ & 838,64 & 909,45 & 7,79 \\
Santos Dumont (35) & 93,86 & 87,47 & $-7,32$ & $3.526,02$ & $3.539,68$ & 0,39 \\
São Jorge (36) & 69,55 & 57,85 & $-20,23$ & 184,02 & 156,05 & $-17,92$ \\
São Lourenço (37) & 61,83 & 50,49 & $-22,46$ & 92,91 & 75,22 & $-23,52$ \\
São Miguel (38) & 46,10 & 30,74 & $-49,98$ & 101,26 & 76,78 & $-31,89$ \\
Vila Irene (39) & 71,27 & 48,75 & $-46,19$ & 239,30 & 306,03 & 21,81 \\
Vila Mariana (40) & 30,98 & 13,83 & $-124,05$ & 72,43 & 40,87 & $-77,21$ \\
Vila Nova (41) & 78,96 & 68,65 & $-15,03$ & 350,16 & 562,82 & 37,78 \\
Vila Real (42) & 87,47 & 68,52 & $-27,67$ & $1.606,37$ & $1.404,60$ & $-14,36$ \\
Vitória Régia (43) & 62,38 & 47,91 & $-30,19$ & 257,73 & 268,20 & 3,90 \\
\hline Org.: The
\end{tabular}

Org.: The authors (2016).

Approximately $20.93 \%$ of the neighborhoods were classified on average of ICV and $4.65 \%$ with a low ICV, such as Cohab Velha (10) and Santa Izabel (32) with less than $10 \%$ vegetation in their respective territories.

The spatial arrangement of the vegetation cover showed that there are low vegetation cover values in the Centro (06) and adjacent districts and in the housing complexes, which were constructed in the period analyzed. The highest vegetation cover values are in the peripheral neighborhoods, close to the rural area.

Regarding the Vegetation Cover Index per Inhabitant, some special situations were observed as follows:

1. In 8 neighborhoods $(18.60 \%)$ there was an increase in the number of inhabitants, with a reduction of vegetation, which implied a reduction in ICVH;

2. The number of inhabitants remained stable, with a reduction of both vegetation and ICVH in 2 neighborhoods, representing $4.65 \%$ of the urban perimeter;

3. Reduction of inhabitants, increase of vegetation and increase of ICVH in 1 neighborhood, totaling $2.33 \%$ of total;

4. In 12 districts (27.91\%) there was a reduction in the number of inhabitants, vegetation, and an increase in ICVH. This fact can be attributed to the compensation of the loss values between the variables, that means that the reduction of inhabitants was accentuated and compensated for that of vegetation areas;

5. In 6 districts, representing $13.95 \%$, there was a reduction of inhabitants, of vegetation, and $\mathrm{ICVH}$, evidencing in this case a direct relation;

6. In 10 neighborhoods (23.26\%) there was a reduction of inhabitants and vegetation, but the ICVH presented stability, that means that the values of the index presented minimal changes;

7. In 3 neighborhoods (6.98\%), the number of inhabitants changed little, but there was a reduction of vegetation, which did not change the ICVH that therefore remained stable.

The ICVH (Table 5) depends on the socio-environmental conditions of each neighborhood analyzed, since the decrease in population is not directly related to the reduction of vegetation and those factors that suppress vegetation, such as the construction on new lots. So if the plot is not occupied, as it was found in the Vila Real 
neighborhood (42), there is no increase in the population of the neighborhood that would lead to a decrease in the index.

The dynamics of the Vegetation Cover Index per Inhabitant showed that it decreased by $37.20 \%$ of the neighborhoods from Cáceres, remained stable in $32.55 \%$ and increased in $30.25 \%$. In this way, the increase of land use class contributed to the reduction of vegetation, as well as the decrease of the population, associated to the vegetation of the neighborhoods, influenced in the decrease of the ICVH.

\section{CONCLUSIONS}

Cáceres underwent an expansion of accumulated areas in parallel with a reduction of vegetation cover and population increase and income;

There is a correlation between land use and vegetation use as well as between population and income;

In the neighborhoods of Cáceres, in the analyzed period, the ICV was high and the ICVH decreased due to space appropriation, mainly for residential purposes;

It is suggested to the public power to implement urban parks and an urban green reserve, considering that Cáceres does not have such categories of public spaces.

\section{REFERENCES}

ALLASIA, D. G.; COLLISCHONN, W.; TUCCI, C. E. M.; GERMANO, A.; COLLISCHONN, B.; FAILACHE, N. Modelo hidrológico da bacia do Alto Paraguai. In: SIMPÓSIO DO CENTRO OESTE DE hIDROlogiA, 3. Porto Alegre, 2004. Anais... Porto Alegre, 2004.

BARGOS, D. C.; MATIAS, L. F. Áreas verdes urbanas: um estudo de revisão e proposta conceitual. Revista da Sociedade Brasileira de Arborização Urbana, Curitiba, v. 6, n. 3, p. 172-88, jul./set. 2011.

BELIZARIO, W. S. Impactos ambientais decorrentes da expansão urbana no córrego pipa em aparecida de Goiânia, Goiás. Revista Mirante, Anápolis (GO), v. 7, n. 2, dez. 2014.

BERTRAND. G. Paisagem e geografia física global. RA'E GA, Curitiba, v. 8, n. 1, p. 141-152, 1972.

BORGES, C. A. F.; MARIM, J. C.; RODRIGUES, J. E. C. Mapeamento da cobertura vegetal do bairro da Marambaia - Belém/PA. REVSBAU, Piracicaba(SP), v. 7, n. 4, p. $1626,2012$.

BRASIL. Casa Civil. Decreto no 6.820, de 13 de abril de 2009. Dispõe sobre a composição e as competências do Comitê de Participação no Fundo Garantidor da Habitação Popular -CPFGHab e sobre a forma de integralização de cotas no Fundo Garantidor da Habitação Popular - FGHab. Diário Oficial [da] República Federativa do Brasil - DOU, Poder Executivo, Brasília, DF, 13 abr. 2009. Seção 1, p. 2.

BRASIL. Secretaria de Meio Ambiente e Recursos Hídricos.. Caderno da Região Hidrográfica do Paraguai.. Brasília: Ministério do Meio Ambiente, 2006. 140 p. 
BRASIL. Casa Civil. Lei 11977 de 07 de julho de 2009. Dispõe sobre o programa minha casa minha vida - PMCMV. Diário oficial [da] República Federativa do Brasil DOU, Poder Executivo. Brasília, DF, 8 jul. 2009. Seção 1, p. 1

BRASIL. Casa Civil. Lei 12424, de 16 de junho de 2011. Altera a Lei no 11.977, de 7 de julho de 2009, que dispõe sobre o Programa Minha Casa, Minha Vida - PMCMV. Diário oficial [da] República Federativa do Brasil - DOU, Poder Executivo. Brasília, DF, 20 jun. 2011.Seção 1, p. 1.

BRASIL. Casa Civil. Lei 6766, de 19 de dezembro de 1979. Dispõe sobre o Parcelamento do Solo Urbano e dá outras Providências. Diário oficial [da] República Federativa do Brasil - DOU, Poder Executivo. Brasília, DF, 20 dez. 1979. Seção 1, p. 1.

BRASIL. Censo demográfico 2000 - Agregado de setores censitários dos resultados do universo. v. 5, região Centro-Oeste. Rio de Janeiro: Instituto Brasileiro de Geografia e Estatística, 2013. Disponível em: http://www.ibge.gov.br/home/ estatistica/populacao/censo2000/defaulttab_munic.shtm. Acesso em: 20 de março de 2016.

BRASIL. Censo demográfico 2010 - Agregado de setores censitários dos resultados do universo. v. 5, região Centro-Oeste. Rio de Janeiro: Instituto Brasileiro de Geografia e Estatística, 2013. Disponível em: http://www.ibge.gov.br/home/ estatistica/populacao/censo2010/default.shtm. Acesso em: 02 de abril de 2016.

BRASIL. Ministério das Minas e Energia. Secretaria Geral. Projeto RADAMBRASIL, Folha SE. 21 Corumbá e parte da folha SE. 20; Geologia, Geomorfologia, Pedologia, Vegetação e uso potencial da terra. Rio de Janeiro, 1982. 452p.

CÂMARA, G.; SOUZA, R. C. M.; FREITAS, U. M.; GARRIDO, J. SPRING: Integrating remote sensing and GIS by object-oriented data modeling. Lisboa-Portugual. Computers \& Graphics, v. 20, n. 3, p. 395 - 403, mai./jun. 1996.

COCHEV, J. S.; NEVES, S. M. A. S.; NEVES, R. J. Espaço urbano de Cáceres/MT analisado a partir de imagens de sensoriamento remoto e SIG. Revista GeoPantanal, Corumbá(MS), v. 5, n. 8, p. 145-160, 2010.

ESRI. ArcGis advanced: release 10.5. Redlands, CA: Environmental Systems Research Institute, 2017.

FLOREZANO, T. G. Iniciação em sensoriamento remoto. 3 ed. São Paulo: Oficina de textos, 2011. 128p.

FRARINA, F. C. Abordagem sobre as técnicas de geoprocessamento aplicadas ao planejamento e gestão urbana. Cad. EBAPE, Rio de Janeiro, v. 4, n. 4. p. 1-13, dez. 2006.

GOMES, M. F.; QUEIROZ, D. R. E. Avaliação da cobertura vegetal arbórea na cidade de Birigui com emprego de técnicas de geoprocessamento e sensoriamento remoto. Revista Geografar, Curitiba, v. 6, n. 2, p. 93-117, dez. 2011.

HENKE-OLIVEIRA, C. Planejamento ambiental da cidade de São Carlos (SP) com ênfase nas áreas públicas e áreas verdes: diagnósticos e propostas. 181p. 1996. Dissertação (Mestrado em Ecologia) - Universidade Federal de São Carlos. UFSCAR, São Carlos/ SP, 1996.

MASCARÓ, L. Ambiência urbana. Porto Alegre, Ed. Sagra, DC Luzzatto, 1996.

MELO, E. F. R. Q.; ROMANINI, A. A gestão da arborização urbana na cidade de Passo fundo/RS. REVSBAU - Revista da Sociedade Brasileira de Arborização Urbana. Piracicaba - SP v. 2, n. 1, p. 1 - 16, 2007. 
MICROSOFT. Pacote Office (Word, Exel, Power Point) Profissional (em Português), 2013.

MINITAB. Minitab for Windows Release 16. State College: Minitab Inc., 2009.

MONTEIRO, C. A. F. Teoria e Clima Urbano. São Paulo: Universidade de São Paulo/ Instituto de Geografia, 1976. $181 \mathrm{p}$.

NEVES, S. M. A. S.; CRUZ, C. B. M.; NEVES, R. J.; SILVA, A. Geotecnologias aplicadas na identificação e classificação das unidades ambientais do pantanal de Cáceres/MT Brasil. Geografia, Rio Claro, v. 34, Número Especial, p. 795-805, dez. 2009.

NEVES, S. M. A. S.; NUNES, M. C. M.; NEVES, R. J. Caracterização das condições climáticas de Cáceres/MT Brasil, no período de 1971 a 2009: subsídios às atividades agropecuárias e turísticas municipais. Boletim Goiano de Geografia, Goiânia, v. 31, n. 2, p. 55-68, 2011.

NUCCI, J. C. Qualidade ambiental e adensamento urbano: um estudo da ecologia e do planejamento da paisagem aplicado ao distrito de Santa Cecília (MSP). São Paulo: Humanitas / FFLCH / USP, 2001.

NUCCI, J. C; Cavalheiro, F. Cobertura vegetal em áreas urbanas - conceito e método. Geousp, São Paulo, v. 2, n. 6, p. 29-36, 1999.

OLIVEIRA, L. A. P. DE; SIMÕES, C. C. DA S. O IBGE e as pesquisas populacionais. Revista Brasileira de Estudos de População, São Paulo, v. 22, n. 2, p. 291-302, jul./dez. 2005.

RABELLO, R. P.; RODRIGUES, Z. A. L. Planejamento e sustentabilidade urbana: ações de proteção dos Igarapés de Manaus. Revista Meio Ambiente e Sustentabilidade, Curitiba, v. 3, n. 2, p. 80-101, jan./jun. 2013.

ROMANO, R. G. Análise ambiental dos instrumentos legais planejamento e gestão urbana sob o enfoque do Programa Minha Casa, Minha Vida. Revista Meio Ambiente e Sustentabilidade, Curitiba, v. 9, n. 4, p. 52-75, jul./dez. 2015.

SANTOS, F. M. M. Clima urbano de Cuiabá-MT-Brasil: ocupação do solo e suas influências. Revista REMOA, v. 12 n. 12, p. 2749 - 2763, ago., 2013.

SANTOS, M. Metamorfoses do espaço habitado. São Paulo: Hucitec, 1988. 136p. SCHEUER J. M.; NEVES, S. M. A. S. Planejamento urbano, áreas verdes e qualidade de vida. Revista Meio Ambiente e Sustentabilidade, v. 11, n. 5, p. 60-73, jun/ dez., 2016.

SILVA, J. S. V.; ABDON, M. M. Delimitação do pantanal brasileiro e suas sub.regiôes. Pesquisa agropecuária brasileira., Brasilia, v. 33, Número Especial, p. 1703-171 out., 1998.

SIQUEIRA, M. M.; MORAES, M. S. Saúde coletiva, resíduos sólidos urbanos e os catadores de lixo. Ciênc. saúde coletiva, Rio de Janeiro, v. 14, n. 6, p. 2115-2122, 2009.

SITTE, C. A construção das cidades segundo seus princípios artísticos. São Paulo, Ed. Ática, 1992. 239 p. 